\title{
Most Favored Nation Clauses in Self-Funded Health Insurance Policies: A Useful Tool Still AVAILABLE To Indiana EMPlOYERS
}

\author{
JAMES DRew Young ${ }^{*}$
}

\section{INTRODUCTION}

When providing health insurance for employees, most businesses have similar goals: obtain the broadest coverage with the finest care for the lowest cost. So pervasive are these goals that many health insurance companies specifically emphasize them in an attempt to attract new clients. Michigan's largest health insurance agency, ${ }^{1}$ Blue Cross Blue Shield of Michigan ("Blue Cross Blue Shield"), is no exception to this generalization. On its website, Blue Cross Blue Shield specifically states that its "unique vision and mission" is to provide its members with "higher quality health care" and "lower health care costs" from "[t]he largest network of doctors and hospitals in the state."

Attempting to deliver on these promises, Blue Cross Blue Shield began using a contract provision called a Most Favored Nation Clause ("MFN") in its agreements with Michigan health care providers. ${ }^{3}$ These provisions guaranteed Blue Cross Blue Shield's clients the most competitive prices in the health care industry by requiring hospitals and other health care providers to grant Blue Cross Blue Shield clients the lowest rates. ${ }^{4}$ As a result, a Blue Cross Blue Shield client seeking medical attention for anything from a broken bone to a heart attack was contractually entitled to a hospital's lowest price for the specific medical attention. $^{5}$

Generally, an MFN is a contractual provision used in buyer-seller relationships that requires the seller to provide the buyer with prices as low as or lower than those paid by any other buyer. ${ }^{6}$ The clause has been used in a variety of business contexts, from contracts guaranteeing manufacturers the lowest price on raw materials to certain licensing and royalty agreements. ${ }^{7}$ In the health care

* J.D. Candidate, 2016, Indiana University Robert H. McKinney School of Law; B.S. 2011, Indiana University, Bloomington, Indiana. Special thanks to Professor Max Huffman.

1. City of Pontiac v. Blue Cross Blue Shield of Mich., No. 11-10276, 2012 WL 1079885, at *1 (E.D. Mich. Mar. 30, 2012).

2. Our Difference, Blue Cross Blue Shield Michigan, http://www.bcbsm.com/ index/about-us/why-choose-us/our-difference.html [perma.cc/JJZ9-2V7S] (last visited Feb. 20, 2016).

3. City of Pontiac, 2012 WL 1079885, at *1.

4. Id. at $* 2$.

5. Id.

6. Beth Ann Wright, How MFN Clauses Used in the Health Care Industry Unreasonably Restrain Trade Under the Sherman Act, 18 J.L. \& HeAlth 29, 30 (2004).

7. Most Favored Nation Pricing: Are Your Suppliers Holding Up Their End of the Bargain?, DeloiTtE \& TouChe LLP (2011), http://www.deloitte.com/assets/Dcom-UnitedStates/ Local\%20Assets/Documents/AERS/us_aers_CRC_Most\%20Favored\%20Nation_120211.pdf 
industry, MFNs are inserted by health insurance companies into "payor-provider" contracts, which are agreements that add health care providers, such as hospitals or medical specialists, to a health insurance company's provider network. ${ }^{8}$ In this setting, a health insurance company - the buyer-uses an MFN to ensure the health care provider - seller - will not charge the buyer more than any other patient for health care services. ${ }^{9}$ Aside from guaranteeing the most competitive health care prices, MFNs may also reduce Blue Cross Blue Shield's transactional costs that accrue from constantly negotiating with health care providers for the lowest prices - savings that may be passed on to the insurer's clients, who are the end consumers. ${ }^{10}$ Since such an arrangement confers an immense, unilateral benefit on the insurance company - the buyer-, a significant amount of market power is typically required of the insurance company before it is able to negotiate the inclusion of an MFN into its payor-provider contracts. ${ }^{11}$

In 2007, Blue Cross Blue Shield possessed the requisite market power to impose MFNs on Michigan's health care providers. ${ }^{12}$ The insurance company covered more than sixty percent of Michigan's commercially insured population; roughly nine times as many as its next largest competitor. ${ }^{13}$ Due to this extensive customer base, Michigan's health care providers could simply not afford to be excluded from Blue Cross Blue Shield's network and were forced to accept a deal on Blue Cross Blue Shield's terms. ${ }^{14}$ This led to the inclusion of MFNs in payor-provider contracts with seventy of Michigan's 131 general acute care hospitals, which operated more than forty percent of the hospital beds in the entire state. ${ }^{15}$

Blue Cross Blue Shield profited significantly from these agreements; however, the manner in which it leveraged the MFNs suggests the savings were not exactly passed through to its customers. ${ }^{16}$ In fact, some argued the provisions were detrimental to Michigan's health care market. ${ }^{17}$ Eventually, the Antitrust Division of the Department of Justice and the city of Pontiac, Michigan filed suit

[perma.cc/4PH3-RKMF].

8. James F. Dougherty Jr., Most Favored Nation Clauses in Payor/Provider Agreements, 9 HMO's \& HEALTH Plans 1 (2006), available at http://www.healthlawyers.org/Members/ PracticeGroups/PPMC/Documents/HMOS_Feb06.pdf [perma.cc/57AZ-SGEJ].

9. Wright, supra note 6, at 30-31.

10. Jonathan R. Slabaugh, DOJ/FTC Workshop: Antitrust Enforcement and Policy of "MostFavored-Nation" Clauses, A.B.A., http://www.americanbar.org/groups/young_lawyers/ committees/doj_ftc_workshop_antitrust_enforcement.html [perma.cc/C4ZJ-WDP7] (last visited Feb. 20, 2016).

11. Wright, supra note 6 , at 30.

12. City of Pontiac v. Blue Cross Blue Shield of Mich., No. 11-10276, 2012 WL 1079885, at *1 (E.D. Mich. Mar. 30, 2012).

13. Id.

14. Id.

15. Id.

16. Id.

17. Id. 
against Blue Cross Blue Shield, claiming that the company's use of the MFN clauses was anticompetitive in nature and violated both national and state-wide antitrust laws. ${ }^{18}$

The complaint claimed that Blue Cross Blue Shield's use of MFNs in its payor-provider contracts harmed competition in the local health insurance market and was a per-se violation of section one of the Sherman Antitrust Act. ${ }^{19}$ A proposed class action lawsuit was filed in the United States District Court for the Eastern District of Michigan against Blue Cross Blue Shield, as well as twentytwo local hospitals, for "conspir[ing] and engag[ing] in anticompetitive conduct." ${ }^{20}$ The complaint maintained Blue Cross Blue Shield used the MFNs to fix prices for health care services and to form barriers-to-entry in the local health insurance market. ${ }^{21}$ It accused Blue Cross Blue Shield of paying the health care providers in its network prices that were above fair market value and then leveraging the MFNs to ensure that potential new market entrants were forced to pay at least the same rates. ${ }^{22}$ The complaint maintained the maneuver resulted in squeezing the profit margins of smaller health insurance companies and crowding out any new market entrants who could not pay the inflated prices. ${ }^{23}$

However, despite Blue Cross Blue Shield's alleged misconduct, the court rejected the argument the use of MFNs in payor-provider contracts is per se illegal and dismissed the case. ${ }^{24}$ By dismissing the case, the court held MFN provisions are not necessarily illegal; however, the complaint demonstrated a few of the primary concerns regarding MFN provisions. For example, although insurance companies undeniably benefit from including MFNs in payor-provider contracts, the provisions are easily abused, may have anticompetitive effects on the health care market, and raise significant antitrust issues. ${ }^{25}$

The potential anticompetitive effects alleged in City of Pontiac v. Blue Cross Blue Shield of Michigan have prompted additional litigation and led roughly twenty state governments, including the Indiana General Assembly, to ban the use of MFNs in health insurance contracts. ${ }^{26}$ They have also led to the publication of multiple articles criticizing the harmful effects of MFNs in the health insurance industry and forecasting harsher federal enforcement in the future. ${ }^{27}$ However, the illegality of MFNs is far from established-neither
18. Id.
19. $I d$.
20. Id.
21. Id. at $* 2$.
22. Id.
23. Id.
24. $I d$. at $* 9$.
25. Bob Cook, States Strike at "Most Favored" Pay Clause, Amednews.com (Nov. 12, 2007), http://www.amednews.com/article/20071112/business/311129998/2/ [perma.cc/3UZY-
26. Id.
27. Id. ZXDL]. 
Congress nor federal courts has taken action to condemn them. ${ }^{28}$ This resistance to act is, in part, due to the potentially positive effects MFNs may have if utilized in a procompetitive manner. ${ }^{29}$

Thankfully for Indiana employers, although the Indiana General Assembly outlawed using MFNs in contracts with health care providers in some cases, employers may continue to use MFNs legally and capitalize on their cost-saving benefits if certain criteria is met. ${ }^{30}$ An analysis of Indiana's anti-MFN statute, the federal Employee Retirement Income Security Act of 1974 ("ERISA") and recent antitrust case law show that when used in a procompetitive manner, MFNs remain perfectly legal. ${ }^{31}$

The purpose of this Note is to demonstrate the continued legality of MFNs when used by Indiana employers to provide health insurance for their employees, present MFNs as a safe and viable option for certain Indiana employers to pursue, and highlight a few potential antitrust issues that Indiana employers should avoid when implementing MFNs into contracts with health care providers. Part I of the Note proves the continued legality of MFNs in Indiana by examining the employer exemption to Indiana's anti-MFN statute, as well as the secondary layer of protection and "safety net of legality" provided by ERISA. Part II then summarizes the current landscape of MFNs in antitrust law, which Indiana employers should be aware of before incorporating MFNs into contracts with health care providers.

\section{The Continued Legality of MFNs in Indiana}

In the fall of 2007, roughly the same time antitrust claims were being filed against Blue Cross Blue Shield of Michigan, Indiana was swept into a growing anti-MFN movement. ${ }^{32}$ It became one of several states to ban the use of MFNs in health insurance contracts when the Indiana General Assembly enacted Indiana Code section 27-8-11-9. ${ }^{33}$ In doing so, Indiana joined ten states that had "either bann[ed] the clauses or plac[ed] restrictions on which plans might use them." ${ }^{34}$ The movement against MFN clauses garnished support on the heels of "widely varying and inconsistent federal court rulings that failed to establish consensus on whether most-favored-nation clauses violate antitrust laws." 35 Insurance companies adamantly defended the utility of MFNs, arguing that they promoted competition between health care providers and primarily benefited consumers who paid less for health care. ${ }^{36}$ However, Indiana physicians

28. See generally 29 U.S.C. § 1144 (2012).

29. Wright, supra note 6 , at 31.

30. IND. CODE $§ 27-8-11-9$ (2015).

31. 29 U.S.C. $\S 1144$.

32. Cook, supra note 25.

33. Id.

34. Id.

35. Id.

36. Id. 
disagreed, maintaining the provisions were unfair to doctors and consumers for the same reasons demonstrated in City of Pontiac v. Blue Cross Blue Shield of Michigan - dominant health insurers use them to set a price floor in the market and freeze out competitors. ${ }^{37}$ The American Medical Association was also involved in the charge against MFNs, demonstrated by former President Dr. William G. Plested III's statement that "[m]ost-favored-nation status ought to be earned. You ought to be able to say, "This insurer treats me better than anyone else, therefore I will grant him the lowest price I will offer anybody."'38

It is important to note, however, Indiana's anti-MFN statute does not necessarily mean MFNs are illegal in all cases. In fact, two independent provisions in two separate statutes allow Indiana employers to continue to use MFNs in contracts with health care providers: the employer exemption in Indiana's anti-MFN statute and the Preemption Provision in ERISA.$^{39}$ First, and most importantly, Indiana's anti-MFN statute specifically exempts Indiana employers from adhering to its terms, so long as they are providing health insurance to their employees. ${ }^{40}$ This means that, so long as the employer is contracting directly with the health care provider to offer health insurance to its employees, it may include an MFN in the agreement. ${ }^{41}$

Secondly, independent of Indiana's anti-MFN statute, a "safety net of legality" is created by ERISA's preemption provision. ${ }^{42}$ ERISA is a federal regulation that covers all plans offered to employees by their employers, known as "employee benefit plans." ${ }^{43}$ In order to regulate all employee benefit plans nationwide in a consistent and predictable manner, ERISA includes a powerful preemption provision that insulates employee benefit plans from state laws. ${ }^{44}$ The preemption provision states ERISA "shall supersede any and all State laws insofar as they may now or hereafter relate to any employee benefit plan." 45 Since certain employer-provided health insurance policies qualify as "employee benefit plans," they are subject to ERISA and its preemption power. Thus, a "safety net of legality" is created that ensures an Indiana employer may use MFNs in its contracts with health care providers.

37. Id.; see also City of Pontiac v. Blue Cross Blue Shield of Mich., No. 11-10276, 2012 WL 1079885, at*1 (E.D. Mich. Mar. 30, 2012).

38. Cook, supra note 25.

39. IND. CODE $§ 27-8-11-9$ (b) (2015); 29 U.S.C. $§ 1144(a)$ (2012).

40. IND. CODE $§ 27-8-11-9(\mathrm{~b})$.

41. Id.

42. See 29 U.S.C. $\S 1144$.

43. Id.; Julie K. Swedback, The Deemer Clause: A Legislative Savior for Self-Funded Health Insurance Plans Under the Employee Retirement Income Security Act of 1974, 18 WM. MITCHELL L. REV. 757, 759 (1992).

44. Swedback, supra note 43 , at 758 .

45. 29 U.S.C. $\S 1144(a)$. 


\section{A. Indiana's Anti-MFN Statute and the Employer Exemption}

The Indiana General Assembly refused to enact Indiana Code section 27-811-9 (the "anti-MFN statute") three times before it was finally passed with the support of Indiana's medical community, small businesses, and those Indiana insurance companies with small degrees of market penetration. ${ }^{46}$ The statute states, in relevant part:

(b) An agreement between an insurer and a provider under this chapter may not contain a provision that:

(1) prohibits, or grants the insurer an option to prohibit, the provider from contracting with another insurer to accept lower payment for health care services than the payment specified in the agreement;

(2) requires, or grants the insurer an option to require, the provider to accept a lower payment from the insurer if the provider agrees with another insurer to accept lower payment for health care services;

(3) requires, or grants the insurer an option of, termination or renegotiation of the agreement if the provider agrees with another insurer to accept lower payment for health care services; or

(4) requires the provider to disclose the provider's reimbursement rates under contracts with other insurers. ${ }^{47}$

The statute clearly and explicitly bans the use of MFN provisions in all agreements "between an insurer and a provider." ${ }^{48}$ However, an examination of the statute's definition of "insurer" reveals that the anti-MFN statute explicitly exempts Indiana employers from adhering to its provisions ("employer exemption"). ${ }^{49}$

Subsection (a) of Indiana Code section 27-8-11-9 states, "[a]s used in this section, 'insurer' includes the following: (1) An administrator licensed under IC 27-1-25; [and] (2) A person that pays or administers claims on behalf of an insurer." ${ }^{50}$ The phrase, "an administrator licensed under IC section 27-1-25," refers to an Insurance Administrator that is governed and regulated by the Indiana Department of Insurance. ${ }^{51}$ The Indiana Department of Insurance is a department in the state government that oversees "the organization, supervision, regulation, examination, rehabilitation, liquidation, and/or conservation of all insurance companies to which this title is applicable." 52 According to Indiana Code section 27-1-25-1(a), the statute's definition of an "administrator" is a "person who directly or indirectly and on behalf of an insurer underwrites, collects charges or premiums from, or adjusts or settles claims on residents of Indiana in connection

46. Cook, supra note 25.

47. IND. CODE $\S 27-8-11-9$ (b) (2015) (emphasis added).

48. Id.

49. Id.

50. Id. $\S 27-8-11-9$ (a) (emphasis added).

51. See id. $\S 27-1-25-1$.

52. Id. $\S 27-1-1-1$. 
with life, annuity, or health coverage offered or provided by an insurer." ${ }^{, 53}$ More importantly, the definition of an "administrator" does not include: "(1) An employer or a wholly owned direct or indirect subsidiary of an employer acting on behalf of the employees of: (A) the employer; (B) the subsidiary; or (C) an affiliated corporation of the employer." 54

Therefore, Indiana's anti-MFN statute prohibits "insurers" from including MFN provisions in any agreement with a provider; however, not included in the statute's definition of "insurers," and thus exempted from its provisions, are "employer[s] acting on behalf of the employees of . . the employer." ${ }^{55}$ The practical effect is, despite the unavailability of MFNs to insurance companies, Indiana employers may still use them in payor-provider contracts when providing health insurance plans to their employees.

\section{B. The "Safety Net of Legality" Provided by ERISA and Its Preemption Provision}

In addition to the protection provided by the employer exemption in Indiana's anti-MFN statute, Indiana employers may ensure their use of MFNs in contracts with health care providers is permissible by structuring their health care plans to fall under ERISA's jurisdiction. ERISA governs every "employee benefit plan" offered by employers nationwide and is silent on the issue of MFNs. ${ }^{56} \mathrm{In}$ order to promote consistent enforcement, employee benefit plans are subject to federal ERISA regulations, which preempt State laws that "now or hereafter relate to any employee benefit plan." ${ }^{57}$ Therefore, an employer who structures its health insurance policy as an ERISA employee benefit plan may establish a "safety net of legality" that occurs when ERISA preempts Indiana's anti-MFN statute.

An ERISA "Employee Benefit Plan" is defined as "any employee benefit plan ... established or maintained ... (1) by any employer engaged in commerce or in any industry or activity affecting commerce; or (2) by any employee organization or organizations representing employees engaged in commerce or in any industry or activity affecting commerce." 58 This extremely broad definition covers a large spectrum of programs, from employee pensions to life insurance. It also includes a health insurance plan that is already popular with many Indiana employers: self-funded health insurance policies. ${ }^{59}$

1. Fully Insured v. Self-Funded Health Insurance Plans.-There are two general categories of health insurance plans available to employers: fully insured health insurance policies and self-insured or "self-funded" health insurance

53. Id. § 27-1-25-1(a).

54. Id. (emphasis added).

55. Id.; id. § 27-8-11-9.

56. Swedback, supra note 43 , at 760.

57. 29 U.S.C. $§ 1144(a)$ (2012).

58. Id. § 1003(a).

59. Swedback, supra note 43 , at 759-60. 
policies. ${ }^{60}$ The fundamental distinction between the two plans is centered on which party - the employer or an insurance company-will pay the health care bills incurred by the plan's participants. ${ }^{61}$ Restated, the chosen plan designates which party bears the risk an employee enrolled in the plan will unexpectedly require substantial and expensive health care costs. ${ }^{62}$

In fully insured health insurance policies, the insurance company assumes both roles. ${ }^{63}$ Fully insured plans are well known to the average consumer as the traditional form of group health insurance.$^{64}$ In the typical fully insured health plan, the employer pays an insurance company a fixed annual rate for coverage, as well as a fluctuating monthly premium for each employee that chooses to enroll in the plan. ${ }^{65}$ The insurance company is then responsible for paying the health care costs accrued by the enrolled employees depending on the benefits provided by the specific policy. ${ }^{66}$ In such a fully insured plan, the insurance company profits by pocketing margins created by the difference in the premiums collected and the health care costs actually incurred. ${ }^{67}$ Therefore, the insurance company is essentially gambling that the premiums it collects are higher than the employees' health care costs. In this way, the insurance company assumes the risk an enrollee may face significant and expensive health care needs in the future (often described as "catastrophic claims"). ${ }^{68}$

Conversely, self-funded health insurance policies are health insurance plans in which "the risk [of catastrophic claims] is borne by the employer." ${ }^{69}$ In selffunded plans, employers pay their employee's health care bills directly, assuming the risk of catastrophic claims but saving on the premium payments an insurance company would collect in a fully insured plan. ${ }^{70}$ In addition to cost savings, selffunded plans provide employers with the ability to assume the increased level of risk with a variety of benefits. ${ }^{71}$ The primary benefit of self-funded plans is that they are extremely flexible and are known for their ability to give employers more flexibility in controlling employee benefit plans. Because self-funded plans

60. Definitions of Health Insurance Terms, Bureau LaB. Stat. 2, 6, www.bls.gov/ncs/ebs/ sp/healthterms.pdf [http://perma.cc/78VE-8FCB] (last visited Feb. 20, 2016).

61. Timothy Stoltzfus Jost \& Mark A. Hall, Self-Insurance for Small Employers Under the Affordable Care Act: Federal and State Regulatory Options, 68 N.Y.U. AnN. SurV. Am. L. 539, 545 (2013).

62. Id.

63. Id.

64. Definitions of Health Insurance Terms, supra note 60, at 2.

65. Is Self-Funding or Fully Insured Right for Your Company?, PHYSICIANS CARE, http://www.physicianscare.com/content/public/default.aspx?id=330 [http://perma.cc/BFR2-A7AS] (last visited Feb. 20, 2016).

66. Id.

67. $I d$.

68. Id.

69. Jost \& Hall, supra note 61 , at 546.

70. Id.

71. Id. 
may be constructed in a myriad of ways, an employer can cut costs by specifically tailoring a self-funded plan's benefits to fit its needs based on factors such as employee demographics or past claims' history. ${ }^{72}$ Self-funded plans are also exempt from certain state taxes and federal health care regulations, such as the Patient Protection and Affordable Care Act ("ACA"). ${ }^{73}$ Employers who issue self-funded plans are not considered "insurers" within the ACA's statutory definition, so certain provisions, such as the essential benefits requirement, riskadjustment program, market-wide risk pooling program, and "medical loss ratio" requirement simply do not apply. ${ }^{74}$

Traditionally, these benefits were only considered to be available to large employers with the financial means to shoulder the significant administrative costs of operating a self-funded health insurance plan in-house, as well as the risk of possibly crippling catastrophic claims. ${ }^{75}$ However, the emergence of independent specialized services such as "third party administrators" and "stop loss insurance" have expanded the availability of self-funded plans to businesses of all sizes. ${ }^{76}$ A Third Party Administrator ("TPA") is "[a]n individual or firm hired by an employer to handle claims processing, pay providers, and manage other functions related to the operation of health insurance." ${ }^{, 77}$ Independent TPAs allow employers to outsource administrative functions and take advantage of selffunded plans without encumbering its own infrastructure.

Likewise, stop loss insurance coverage makes self-funded health plans an option for smaller employers by allowing these employers to shift some of the risk of a catastrophic claim to an independent insurance company. ${ }^{78}$ In a stop loss insurance policy, an employer pays the majority of health care costs incurred by its employees; however, if expenses surpass a pre-determined threshold (such as a "catastrophic claim"), then the insurance company covers the remainder of the medical bills. ${ }^{79}$ This service effectively "minimizes [the employer's] exposure to unlimited benefits liability" and allows employers to take advantage of a selffunded plan's flexibility. ${ }^{80}$

However, for the purposes of this Note, the definitive feature of self-funded health insurance plans is the contracts with health care providers are entered into by the employer, rather than an insurance company, thereby making the employer exemption of Indiana's anti-MFN statute applicable. Another important characteristic is employer-provided self-funded plans are included within

72. Id. at 540 (noting a narrow example of this would be a small employer with only single, male employees; therefore, excluding pregnancy benefits from its plan's coverage).

73. Id.

74. Id. at 555 .

75. Id. at 546 .

76. Id. at 547 .

77. Definitions of Health Insurance Terms, supra note 60, at 6 .

78. Id.

79. Swedback, supra note 43 , at 759 .

80. Id. 
ERISA's definition of "employee benefit plans." 81 Thus, self-funded policies are under the protection of ERISA's preemption provision, which shelters the employee benefit plans from certain state laws and regulations. ${ }^{82}$ As such, ERISA's preemption provision prevents Indiana's anti-MFN statute from applying to an employer's self-funded health insurance plan and provides a "safety net of legality" for Indiana employers who wish to capitalize on MFNs' cost savings by incorporating them into payor-provider contracts.

2. ERISA's Preemption Provision.-ERISA "comprehensively regulates employee pension and welfare plans" $" 83$ and was promulgated to "protect ... the interests of participants in employee benefit plans and their beneficiaries . . . by establishing standards of conduct, responsibili[ties], and obligation[s] for fiduciaries of employee benefit plans, and by providing for appropriate remedies, sanctions, and ready access to the Federal courts." ${ }^{\prime 4}$

To accomplish its goals of promoting uniformity and ensuring the effectiveness of ERISA's provisions, Congress created "an area of exclusive federal concern," thus insulating ERISA from state laws. ${ }^{85}$ The preemption provision was intended to eliminate the inefficiencies of plans having to comply with conflicting state and federal laws, particularly in the case of multi-state employers. ${ }^{86}$ Specifically, Congress was concerned employers confronted with the high administrative costs that result from complex compliance issues would be forced to either reduce benefits or eliminate employee benefit programs altogether. ${ }^{87}$ Therefore, Congress protected this "area of exclusive federal concern" by granting ERISA a broad preemption power, codified in 29 U.S.C. $\S 1144$ ("the preemption provision"). ${ }^{88}$ This expansive preemption provision ensures that ERISA is not compromised by state law and is the foundation for the "safety net of legality" that can be taken advantage of by Indiana employers.

Confirming that ERISA's preemption provision provides Indiana employers who utilize MFNs with an additional "safety net" requires a three-step analytical process. ${ }^{89}$ Collectively, these three steps are used to walk a tightrope between enabling ERISA to operate effectively and refraining from infringing on states'

81. 29 U.S.C. § 1144(a) (2012); see generally FMC Corp., v. Holliday, 498 U.S. 52 (1990). Note, however, a stop-loss insurance coverage is not protected from ERISA's preemption power.

82. See supra Part I.

83. A welfare plan is defined as "one which provides to employees 'medical, surgical, or hospital care or benefits, or benefits in the event of sickness, accident, disability [or] death,' whether these benefits are provided 'through the purchase of insurance or otherwise." Metro. Life Ins. Co. v. Mass., 471 U.S. 724, 729 (1985) (quoting 29 U.S.C. § 1002(1) (1982)).

84. 29 U.S.C. $\S 1001$ (b) (2012).

85. Swedback, supra note 43, at 762.

86. Troy Paredes, Stop-Loss Insurance, State Regulation, and ERISA: Defining the Scope of Federal Preemption, 34 HARV. J. ON LEGIS. 233, 237-38 (1997).

87. Id.

88. Swedback, supra note 43, at 762; see also 29 U.S.C. $§ 1144$.

89. Swedback, supra note 43, at 763. 
rights. ${ }^{90}$ The first step in ERISA's preemption analysis is an extremely broad presumption that "any and all State laws" even relating to an employee benefit plan are preempted by ERISA provisions. ${ }^{91}$ The second step then provides an exception to the first step's "preemption presumption" and gives control back to the states over three key areas of commerce - the banking, insurance, and securities industries. ${ }^{92}$ This provision, known as the savings clause, "saves" state regulations that relate to these important industries from the first step's overly inclusive presumption of preemptive. ${ }^{93}$ The third and final step in ERISA's preemption analysis reins in the applicability of the savings clause. ${ }^{94}$ Referred to as the "Deemer Clause," the third step restricts the application of the savings clause by preventing a state from "deeming" an employer an "insurance company" solely so the employer's actions will be characterized as "within the insurance industry," thereby becoming subject to the savings clause. ${ }^{95}$ The Deemer Clause is a reaction to states' attempts at forcing employers to comply with state laws that only "purport to regulate insurance companies, insurance contracts, banks, trust companies, or investment companies." ${ }^{" 96}$ Essentially, it prevents state governments from indirectly regulating employee benefit plans. ${ }^{97}$

An application of this three-step analytical process demonstrates employerprovided self-funded health insurance plans are protected from Indiana's antiMFN statute by ERISA's preemption provision. The savings clause would typically save Indiana's anti-MFN statute from preemption because it relates to the insurance industry; however, the Deemer Clause prohibits the savings clause from extending to Indiana employers who issue self-funded health plans. ${ }^{98}$ It prevents the Indiana General Assembly from deeming an Indiana employer an insurer simply to apply the savings clause. Therefore, the anti-MFN statute, which covers "agreement[s] between an insurer and a provider," is inapplicable.

a. Step one: ERISA's broad general preemption.-ERISA's general and extremely broad preemption language is found in 29 U.S.C. $§ 1144$ (a). ${ }^{99}$ It states that, "[e]xcept as provided in [the Savings Clause], the provisions of this subchapter ... shall supersede any and all State laws insofar as they may now or hereafter relate to any employee benefit plan described in section 1003(a) of this title ...." ${ }^{100}$ A self-funded health insurance plan clearly meets $\S 1003(\mathrm{a})$ 's definition of an employee benefit plan, which is described as "any employee benefit plan ... established or maintained (1) by any employer engaged in

90. Id. at 764-65.

91. 29 U.S.C. $§ 1144$ (a) (emphasis added).

92. Swedback, supra note 43 , at 765.

93. Id.

94. Id.

95. Id.

96. Id.

97. Id. at 776 .

98. Id.

99. 29 U.S.C. § 1144(a) (2012).

100. Id. (emphasis added). 
commerce or in any industry or activity affecting commerce"101 Therefore, so long as Indiana's anti-MFN statute sufficiently "relates to" an employer-provided self-funded health insurance plan, it is superseded by ERISA's preemption provision.

The U.S. Supreme Court previously held Congress intended to define the term "relate to" in its broadest sense and that "[a] law 'relates to' an employee benefit plan ... if it has a connection with or reference to such a plan." ${ }^{102}$ This is true regardless of whether the law was designed to be connected with an employee benefit plan or the connection is merely indirect. ${ }^{103}$ However, the Court also said this standard was not unlimited and can in some cases be "too tenuous, remote, or peripheral a manner to warrant a finding that the law 'relates to' the plan." "104 It expanded on this in Egelhoff v. Egelhoff, when it held that to determine whether a state law has a "connection with" an employee benefit plan, a court must look: (1) to ERISA's objectives, and to what extent Congress intended it to survive; and (2) to the nature of the effect that the state law had on ERISA plans. ${ }^{105}$

The U.S. Supreme Court's analytical framework may be used to show Indiana's anti-MFN statute has a strong enough "connection with" ERISA provisions to be sufficiently preempted by $\S 1144$ (a)'s general language. ${ }^{106}$ First, case law has demonstrated one of ERISA's primary goals is to allow employers "to establish a uniform administrative scheme, which provides a set of standard procedures to guide processing of claims and disbursement of benefits." 107 Since Indiana's anti-MFN statute would require multi-state employers to include or exclude MFN clauses in payor-provider contracts depending on the state in which employers are contracting, the statute's practical effect would be to prohibit one of ERISA's main goals: uniformity in employee benefit plan requirements. ${ }^{108}$ Therefore, the anti-MFN statute clearly has a "sufficient connection" with an employee benefit plan and falls within the broad "preemption presumption" in step one of ERISA's preemption analyses. However, Indiana's anti-MFN statute is also within the scope of the savings clause.

b. Step two: the savings clause.-The savings clause, codified in 29 U.S.C. $\S 1144(\mathrm{~b})(2)(\mathrm{A})$, states that "nothing in [the preemption clause] shall be construed to exempt or relieve any person from any law of any State which

101. 29 U.S.C. $\S 1003(a)$.

102. Shaw v. Delta Air Lines, Inc., 463 U.S. 85, 96-97 (1983) (emphasis added); see also Egelhoff v. Egelhoff, 532 U.S. 141, 149 (2000); D.C. v. Greater Wash. Bd. of Trade, 506 U.S. 125, 126 (1992); Ingersoll-Rand Co. v. McClendon, 498 U.S. 133, 139 (1990); FMC Corp. v. Holliday, 498 U.S. 52 (1990).

103. Shaw, 463 U.S. at 96-97.

104. Id. at $100 \mathrm{n} .21$.

105. Egelhoff, 532 U.S. 141.

106. 29 U.S.C. $\S 1144$ (a) (citation omitted).

107. Egelhoff, 532 U.S. at 148 (quoting Fort Halifax Packing Co. v. Coyne, 482 U.S. 1, 9 (1987)).

108. IND. CODE $\S 27-8-11-9$ (2015). 
regulates insurance, banking, or securities."109 The goal of the savings clause is to "make room for a state to regulate" and only state laws that actually "regulate insurance" are "saved." "110 To determine which state laws sufficiently "regulate insurance," a two-pronged test (often referred to as "the Miller test") is used. ${ }^{111}$ The Miller test was promulgated in 2003 by the U.S. Supreme Court in Kentucky Association of Health Plans, Inc. v. Miller, and states a state law "regulates insurance" when "[f]irst, the state law is "specifically directed toward entities engaged in insurance' ... . [and] [s]econd, ... the state law . . . substantially affect[s] the risk pooling arrangement between the insurer and the insured."112 The Supreme Court's opinion in Miller also clarifies the scope of the twopronged test, which demonstrates that, under the test, Indiana's anti-MFN statute would be "saved" from ERISA preemption. ${ }^{113}$

The first prong of the Miller test is facially satisfied by Indiana's anti-MFN statute. ${ }^{114}$ The first prong requires the state law in question to be "specifically directed toward 'insurers' and the insurance industry," 115 a requirement that is necessarily met by the qualifying language in Indiana's anti-MFN statute, which specifically restricts the application of the statute to "agreement[s] between an insurer and a provider." "16 Similarly, Indiana's anti-MFN statute also satisfies the second prong of the Miller test, which requires the state law to "substantially affect the risk pooling agreement undertaken by insurer and insured." "The Court held for a state law to "regulate insurance" they do not have to "alter or control the actual terms of insurance policies ... it suffices that they substantially affect the risk pooling arrangement between insurer and insured." 118 The Court also stated in a footnote:

ERISA's saving clause does not require that a state law regulate insurance companies or even the business of insurance to be saved from pre-emption; it need only be a "law . . . which regulates insurance" ... and self-insured plans engage in the same sort of risk pooling

109. 29 U.S.C. $\S 1144(\mathrm{~b})(2)(\mathrm{A})$ (emphasis added).

110. Beverly Cohen, Saving the Savings Clause: Advocating Broader Reading Miller Test to Enable States to Protect ERISA Health Plan Members by Regulating Insurance, 18 GEO. MASON L. REV. 125, 132 n.47 (2010).

111. See generally Ky. Ass'n of Health Plans, Inc. v. Miller, 538 U.S. 329 (2003).

112. Id. at 342; see also Standard Ins. Co. v. Morrison, 537 F. Supp. 2d 1142, 1149 (D. Mont. 2008), aff'd, 584 F.3d 837 (9th Cir. 2009).

113. Miller, 538 U.S. at 330. Although roughly seven cases have distinguished the Court's holding in Miller, none of the aforementioned cases have precedential authority in the Seventh Circuit.

114. See id. at 342 .

115. Id. at 333 (quoting Ky. Ass'n of Health Plans, Inc. v. Nichols, 227 F.3d 352, 366 (6th Cir. 2000)).

116. IND. CODE $§ 27-8-11-9$ (b) (2015) (emphasis added).

117. Miller, 538 U.S. at 338.

118. Id. 
arrangements as separate entities that provide insurance to an employee benefit plan. ${ }^{119}$

Although this may be merely dicta, the Supreme Court's statement indicates how it would rule in terms of Indiana's anti-MFN statute. Further, courts in other jurisdictions have utilized this apparent dictum to come to comparable decisions. ${ }^{120}$

Applying the Miller test, it is clear that Indiana's anti-MFN law sufficiently "regulates insurance." 2121 Therefore, although Indiana's statute is subject to ERISA's broad preemption provision in 29 U.S.C. $§ 1144$ (a), it is also "saved" for "regulating insurance" by the savings clause in 29 U.S.C. $§ 1144(b)(2)(A) .{ }^{122}$

c. Step three: the Deemer Clause.-Assuming the savings clause applies to Indiana's anti-MFN statute, the applicability of the Deemer Clause is critical to establishing the existence of a "safety net of legality" for Indiana employers who wish to include MFNs in contracts with health care providers. ${ }^{123}$ If the savings clause applies and the Deemer Clause does not, then Indiana's anti-MFN statute is not preempted and the safety net does not exist. ${ }^{124}$ However, if both clauses apply, so does the safety net. The Deemer clause is codified in 29 U.S.C. $\S$ 1144(b)(2)(B) and states:

$[\mathrm{N}]$ either an employee benefit plan . . . shall be deemed to be an insurance company or other insurer, bank, trust company, or investment company or to be engaged in the business of insurance or banking for purposes of any law of any State purporting to regulate insurance companies, insurance contracts, banks, trust companies, or investment companies. ${ }^{125}$

A plain reading of the Deemer Clause demonstrates it is applicable to Indiana's anti-MFN statute, which prohibits MFN clauses in "[a]n agreement between an insurer and a provider." 26 The Deemer Clause states that "an employee benefit plan ... shall [not] be deemed . . . [an] insurer . . . for the purposes of any law of any State purporting to regulate ... insurance companies [or] insurance contracts." ${ }^{127}$ This is the precise scenario for what would need to occur for Indiana's anti-MFN statute to extend to employer-provided self-funded health insurance plans - the employer offering the self-funded health insurance plan would have to be "deemed" an insurer for Indiana's anti-MFN statute to

119. Id. at 336 n. 1 (emphasis added) (internal quotation marks omitted).

120. See, e.g., Prudential Ins. Co. of Am. v. Nat'1 Park Med. Ctr., Inc., 413 F.3d 897, 910 (8th Cir. 2005).

121. See generally Miller, 538 U.S. 329.

122. See supra Part II.

123. See 29 U.S.C. $§ 1144(b)(2)(B)(2012)$.

124. Id.

125. Id. (emphasis added).

126. IND. CODE $§ 27-8-11-9$ (b) (2015) (emphasis added).

127. 29 U.S.C. $\S 1144(b)(2)(B)$. 
apply to any agreement the employer enters into with a provider. ${ }^{128}$ Otherwise, the anti-MFN statute's qualifying language would not reach any agreement between the employer and a provider. ${ }^{129}$

The U.S. Supreme Court's decision in FMC Corp. v. Holliday supports this analysis. ${ }^{130}$ In FMC Corp., the Supreme Court held ERISA preempted the application of the Pennsylvania Motor Vehicle Financial Responsibility Law to self-funded health care plans. ${ }^{131}$ The Court held the self-funded health care plan was an employee welfare benefit plan under ERISA and found "the Deemer Clause to exempt self-funded ERISA plans from state laws that regulat[e] insurance within the meaning of the saving clause."132

However, the Court did make an important distinction: "if a plan is insured, a State may regulate it indirectly through regulation of its insurer and its insurer's insurance contracts; if the plan is uninsured, the State may not regulate it."133 This means if an ERISA employee benefit plan pays a health insurance company for coverage, it may be indirectly regulated by state law through regulations aimed at insurance companies; however, if an ERISA employee benefit plan refrains from hiring an insurance company, it may not be regulated by state law at all. ${ }^{134}$ The Court also held this interpretation of the Deemer Clause was consistent with Congress's intent for ERISA to "establish pension plan regulation as exclusively a federal concern." 135

In summary, although Indiana's anti-MFN statute would otherwise be "saved" under the savings clause in $\S 1144$ (b)(2)(A), it remains preempted by ERISA under the Deemer Clause's application to employer-provided, self-funded insurance plans. ${ }^{136}$ Therefore, a "safety net of legality" exists that allows employers to use MFNs when issuing self-funded health insurance plans to their employees because, even if the employer exemption in Indiana's anti-MFN statute did not exist, the application of the statute to self-funded health plans would be effectively preempted by ERISA.

\section{Antitrust Issues Surrounding the Use of MFNs}

Although Part I sufficiently establishes Indiana employers may still legally use MFNs in their contracts with health care providers, ${ }^{137}$ it is still imperative for employers to have a thorough knowledge of current antitrust law in order to use

128. IND. CODE $§ 27-8-11-9$ (b).

129. See id.

130. See generally FMC Corp. v. Holliday, 498 U.S. 52 (1990).

131. Id.

132. Id. at 61 (internal quotation marks omitted).

133. Id. at 64 (emphasis added) (quoting Shaw v. Delta Air Lines, Inc., 463 U.S. 85, 99 (1983)).

134. Id.

135. Id. at 64 (quoting Alessi v. Raybestos-Manhattan, Inc., 451 U.S. 504, 523 (1981)).

136. 29 U.S.C. $\S 1144(b)(2)(A)$ (2012)

137. See supra Part I. 
MFNs in a procompetitive and legal way. Antitrust suits may still potentially be brought on a case-by-case basis under the Sherman Antitrust Act. ${ }^{138}$ If an Indiana employer applies an MFN incorrectly, it could lead to anticompetitive effects, exposing the employer to potential litigation. ${ }^{139}$ Federal antitrust enforcement agencies, such as the Antitrust Division of the Department of Justice and the Federal Trade Commission, have stated they "recogni[ze] the competitive concerns that MFNs can raise" 140 and "will continue to challenge the use of MFN clauses when the evidence suggests that such terms violate antitrust law."141 However, federal enforcement agencies also admit that "MFNs may be anticompetitive or procompetitive, depending on the circumstances." 142 Thus, if used in a procompetitive manner, MFNs may be incorporated by Indiana employers into payor-provider contracts, without raising antitrust implications.

Complaints alleging antitrust violations resulting from the use of MFN provisions are typically brought under the Sherman Antitrust Act. ${ }^{143}$ Passed in 1890, the Sherman Antitrust Act is "a comprehensive charter of economic liberty aimed at preserving free and unfettered competition." ${ }^{44}$ The Act has two main sections under which predominantly all antitrust claims are brought and which form the basis for most of the antitrust litigation surrounding MFNs. ${ }^{145}$ Section one of the Sherman Act covers unlawful agreements, which includes any contract or agreement that unreasonably restrains trade. ${ }^{146}$ Section two covers the monopolization or attempted monopolization of a relevant market. ${ }^{147}$ In order to avoid antitrust litigation entirely, it is critical that an Indiana employer contemplate the possible effects of an MFN's use according to both sections.

\section{A. The Sherman Antitrust Act, Section One: Unlawful Agreements That Restrain Trade}

Section one of the Sherman Antitrust Act prohibits unlawful agreements that

138. John J. Miles, Payor Monopsony Power-Payer Monopsony Power and Most-FavoredNations Provisions, 2 Health Care \& Antitrust L. § 15B:6 (2015).

139. Id.

140. Id. (citing Charles F. Rule, Assistant Attorney Gen., Antitrust in the Health Care Field: Distinguishing Resistance from Adaptation, Prepared Remarks Before the Antitrust \& Health Care Seminar of the Antitrust Section of the Connecticut Bar Association and the Connecticut Health Lawyers Association (Mar. 11, 1988)).

141. Fed. Trade Comm'n \& Dep't of Justice, Improving Health Care: A Dose of COMPETITION 269 (Jun. 25, 2015), available at http://www.justice.gov/atr/public/health_care/ 204694/chapter6.htm [http://perma.cc/WJ74-2CCH].

142. Id. (emphasis added).

143. Wright, supra note 6 , at 31 .

144. N. Pac. Ry. Co. v. United States, 356 U.S. 1, 4 (1958).

145. City of Pontiac v. Blue Cross Blue Shield of Mich., No. 11-10276, 2012 WL 1079895, at *6 (E.D. Mich. Mar. 30, 2012).

146. 15 U.S.C. $\S 1$ (2012).

147. Id. $\S 2$. 
unreasonably restrain trade. ${ }^{148}$ Codified in 15 U.S.C. $\S 1$, it states, "[e]very contract, combination in the form of trust or otherwise, or conspiracy, in restraint of trade or commerce among the several States, or with foreign nations, is declared to be illegal." "149 In order to prove a section one violation, a plaintiff must demonstrate: (1) the existence of a multi-party agreement that is (2) an unreasonable restraint of trade. ${ }^{150}$ The nuances of proving the existence of a multi-party agreement are inapplicable to this Note because the agreement between the parties will be well documented in the form of a payor-provider contract. Therefore, the most important element in a section one Sherman Act analysis is whether the agreement results in an "unreasonable restraint of trade." 151

1. Unreasonable Restraints of Trade in Section One of the Sherman Act: Per Se v. the Rule of Reason Standard.-Agreements that violate section one of the Sherman Antitrust Act as unreasonable restraints of trade fall into one of two categories: (1) agreements that are conclusively presumed to be unreasonable and are illegal per se; and (2) agreements that are interpreted by the court to be unreasonable as applied, using the rule of reason standard. ${ }^{152}$ An agreement considered to be per se illegal is one that "would always or almost always tend to restrict competition and decrease output." 153 Thus, once a type of agreement is characterized as per se illegal, no further inquiry is required into either the agreement's actual effect on the market nor the intentions of the contracting parties. ${ }^{154}$ This lack of required analysis by a court is due to the tedious and expensive nature of a rule of reason analysis and the inherent anticompetitive characteristics of the specific type of agreement - a court essentially finds that a category is so intrinsically anticompetitive that it is a waste of the court's time and resources to conduct a full analysis. Conversely, the rule of reason standard is applied to those agreements that are ambiguous and whose procompetitive effects may or may not outweigh its anticompetitive effects. ${ }^{155}$ It requires a factspecific test in which the fact finder takes into account the totality of the circumstances surrounding the agreement such as the level of market power possessed by the contracting parties and whether the restraint has an anti or procompetitive effect on the relevant geographic or product markets. ${ }^{156}$

The use of MFNs in payor-provider contracts is not per se illegal because there are enough procompetitive benefits of using MFNs to require a weighing

148. Id. $\S 1$.

149. Id.

150. Wright, supra note 6, at 29.

151. See generally John J. Dvorske, Annotation, Construction and Application of Sherman Act, 15 U.S.C.A. $\S \S 1$ et seq.-Supreme Court Cases, 35 A.L.R. Fed. 2d 1 (2009).

152. City of Pontiac v. Blue Cross Blue Shield of Mich., No. 11-10276, 2012 WL 1079895, at *6 (E.D. Mich. Mar. 30, 2012).

153. Id.

154. Id.

155. Dvorske, supra note 151.

156. Id. 
of these benefits against the anticompetitive effects the MFNs may have. ${ }^{157}$ Further, case law demonstrates that for the per se standard to be applicable, the agreement in question must be a horizontal restraint or an agreement between competitors at the same level of the market structure. ${ }^{158}$ Conversely, a vertical restraint or a restraint caused by combinations or persons at different levels of the market structure must be judged under the rule of reason standard. ${ }^{159}$ A payorprovider contract, which is an agreement between a purchaser of health care and a provider of said services, is a prototypical example of a vertical relationship, where each party is on a different level of the market structure. As such, any agreement that allegedly restrains trade between the two parties is considered a vertical restraint and is always subjected to the rule of reason standard. ${ }^{160}$

2. Applying the Rule of Reason to the Use of MFNs in Payor-Provider Contracts. - An agreement fails the rule of reason analysis if it "may suppress or even destroy competition," rather than promote it. ${ }^{161}$ In order to "state a claim under the [rule of reason] test, a plaintiff must allege, inter alia, that the purportedly unlawful contract, combination, or conspiracy 'produced adverse, anticompetitive effects within relevant product and geographic markets." "'162 Unfortunately, case law applying the rule of reason to the use of MFNs in payorprovider contracts is sparse. There are few private causes of action that allege anticompetitive effects of MFNs in payor-provider contracts and federal enforcement agencies have only filed a total of seven cases challenging this specific use of MFNs. ${ }^{163}$ However, the Department of Justice's Antitrust Division, which has filed six of the seven aforementioned cases, attempted to clarify its policy regarding MFNs by emphasizing two prerequisites necessary for MFNs to be found as having an anticompetitive effect. ${ }^{164}$

First, the employer using the MFN must have such a significant amount of market power "that almost all providers believe that they must participate in that payer's plan." ${ }^{65}$ Secondly, the employer utilizing the MFN must account for a "sufficiently large percentage" of the participating providers' total business, so it would be unprofitable for those providers to contract with others whom are

157. Total Benefits Planning Agency, Inc. v. Anthem Blue Cross \& Blue Shield, 552 F.3d 430, 436 (6th Cir. 2008).

158. Id. at 435 .

159. Id.

160. Id.

161. Am. Needle, Inc. v. Nat'l Football League, 560 U.S. 183, 203 (2010) (quoting Bd. of Trade v. United States, 246 U.S. 231, 238 (1918)).

162. Warrior Sports, Inc. v. Nat'l Collegiate Athletic Ass'n, 623 F.3d 281, 286 (6th Cir. 2010) (emphasis in original) (quoting Crane \& Shovel Sales Corp. v. Bucyrus-Erie Co., 854 F.2d 802, 805 (6th Cir. 1988)).

163. Miles, supra note 138, at 2 (noting the Department of Justice has filed six cases and the Federal Trade Commission has filed one).

164. Id. (citing Rule, supra note 140).

165. Id. 
paying less. ${ }^{166}$ To further clarify, the Antitrust Division stated that a "sufficiently large percentage" is considered to be "at least 35 percent" of the providers" business - a number that is "a function of [both] the number of providers contracting with the payer and the importance of the payer to each provider."167 Thus, before an agreement between an Indiana employer and a health care provider will even be considered to have possible antitrust implications by the Antitrust Division, the number of participants in the employer's self-funded plan must contain greater than a thirty-five percent share in the health care provider marketplace and be so significant that almost all providers believe they must participate in the plan.

It is worth noting that no federal court has held the inclusion of MFNs in payor-provider contracts violates antitrust laws. ${ }^{168}$ This is far from a declaration of legality; many cases have been settled out-of-court, such as the Department of Justice's most recent challenge in United States v. Blue Cross Blue Shield of Michigan. ${ }^{169}$ After the suit survived Blue Cross Blue Shield's Rule 12(b)(6) motion to dismiss for failure to state a claim upon which relief can be granted, the parties reached a settlement, so it was not adjudicated in court. ${ }^{170}$ The lack of precedent results in a legal arena where the effect of MFNs remains a contested issue and one that could fall in favor of treating MFNs favorably. The court in Blue Cross Blue Shield of Michigan held that for the government to survive the motion to dismiss, it must "plausibly allege that the MFNs produced adverse anticompetitive effects within relevant product and geographic markets." ${ }^{171}$ This could hardly be seen as a prohibition on MFNs, as this relaxed standard of "plausibly alleg[ing]" anticompetitive effects is far removed from proving an MFN's anticompetitive effects, which a federal agency or private party must do to obtain a verdict.

In summary, an Indiana employer may glean three important takeaways from potential litigation surrounding section one of the Sherman Antitrust Act. First, as long as the employer does not account for a "sufficiently large percentage" of providers' total business, (or more than thirty-five percent), then it will not be looked at by the federal antitrust enforcement agencies. ${ }^{172}$ Second, even if a federal antitrust enforcement agency (such as the Antitrust Division of the Department of Justice) does investigate an Indiana employer based on its market share, the agency must point to the MFNs specific effect, rather than merely to its general use, in order for its complaint to survive a rule of reason analysis. ${ }^{173}$ Finally, if the federal enforcement agency can "plausibly allege" anticompetitive

166. $I d$.

167. Id.

168. Id.

169. United States v. Blue Cross Blue Shield of Mich., 809 F. Supp. 2d 665, 669 (E.D. Mich. 2011).

170. Id.

171. Id. at 671-72 (emphasis added).

172. Miles, supra note 138 (quoting Rule, supra note 140).

173. Dvorske, supra note 151. 
effects by the employer's MFN, the court must still balance those possible anticompetitive effects with any procompetitive effects the MFN may have. ${ }^{174}$ Combined, these takeaways signify if an MFN is used in a procompetitive manner, an Indiana employer is safe from triggering antitrust implications under section one of the Sherman Act.

\section{B. The Sherman Antitrust Act, Section Two: Monopolization and Attempted Monopolization}

Section two of the Sherman Antitrust Act provides that "[e]very person who shall monopolize, or attempt to monopolize, or combine or conspire with any other person or persons, to monopolize any part of the trade or commerce among the several States, or with foreign nations, shall be deemed guilty of a felony."175 Section two's primary purpose is to prohibit the acquisition or maintenance of monopolies, thereby preserving a competitive environment which "spurs companies to reduce costs, improve the quality of their products, invent new products, educate consumers, and engage in a wide range of other activity that benefits consumer welfare." $" 176$

However, as in section one of the Sherman Antitrust Act, the wording in section two of the statute is vague and relies on judicial interpretation. ${ }^{177}$ Courts have extrapolated from its wording two general types of conduct section two prohibits: actual monopolization and the attempt, or conspiracy to, monopolize. ${ }^{178}$ An "attempted monopolization" is proven by demonstrating "(1) that the defendant has engaged in predatory or anticompetitive conduct with (2) a specific intent to monopolize, and (3) a dangerous probability of achieving monopoly power." 179 The requirement of a party's "specific intent to monopolize" is important because it refers to the party's "specific intent to destroy competition or build monopoly." ${ }^{180}$ Because a successful conviction of an "attempted monopolization" charge requires a business to have been consciously aware it was engaging in illegal conduct or utilizing legal conduct to achieve an illegal end, only actual monopolization will be covered moving forward - the purpose of this Note is to help Indiana employers safely and legally use MFNs in payor-provider contracts, not provide a roadmap on how to circumvent the United States' antitrust laws.

174. Blue Cross Blue Shield of Mich., 809 F. Supp. 2d at 671-72.

175. 15 U.S.C. $\$ 2$ (2012).

176. Dep't of Justice, Competition and Monopoly: Single-Firm Conduct Under SECTION 2 OF THE SHERMAN ACT (2008), available at http:/www.justice.gov/atr/public/ reports/236681_chapter1.htm\#N_27 [http://perma.cc/BHE6-364M] [hereinafter COMPETITION AND MONOPOLY].

177. Id.

178. 15 U.S.C. $\S 2$.

179. Spectrum Sports, Inc. v. McQuillan, 506 U.S. 447, 456 (1993) (emphasis added).

180. Competition And Monopoly, supra note 176 (quoting Times-Picayune Publ'g Co. v. United States, 345 U.S. 594, 626 (1953)). 
In order to prove a section two "monopolization" violation, a plaintiff must demonstrate: "(1) the possession of monopoly power in the relevant market and (2) the willful acquisition or maintenance of that power as distinguished from growth or development as a consequence of a superior product, business acumen, or historic accident." ${ }^{\prime 181}$ Therefore, an Indiana employer's use of an MFN in a payor-provider contract will only be susceptible to a section two violation if it possessed the requisite monopoly power in the health insurance market and used the MFN in an anticompetitive way to acquire or maintain that power. This is unlikely from occurring because several courts (including the Seventh Circuit) have refused to categorize an MFN as an anticompetitive device with which monopolistic power is used. ${ }^{182}$

A paramount principle of the Sherman Antitrust Act is that a monopoly, inand-of-itself, is not illegal. ${ }^{183}$ In fact, a monopoly, like other participants, is encouraged to compete vigorously in the marketplace. ${ }^{184}$ Instead, section two of the Sherman Antitrust Act is exclusively concerned with a monopoly's anticompetitive "exclusionary" or "predatory" conduct. ${ }^{185}$ "Exclusionary" conduct can be defined as "behavior that not only (1) tends to impair the opportunities of rivals, but also (2) either does not further competition on the merits or does so in an unnecessarily restrictive way." aggressively competitive conduct and exclusionary conduct are extremely similar and are difficult for courts to differentiate. ${ }^{187}$ In fact, most conduct contains both competitive and exclusionary effects at the same time. ${ }^{188}$ Thus, it is almost impossible to predict how courts will interpret certain types of conduct. However, precedent does exist in which courts held MFNs do not constitute predatory conduct. ${ }^{189}$

Courts have, on several occasions, upheld the procompetitive effects of MFNs in payor-provider contracts. ${ }^{190}$ In Ocean State Physicians Health Plan, Inc. v. Blue Cross and Blue Shield of Rhode Island, the First Circuit upheld the defendant insurer's use of an MFN (in this case called a "Prudent Buyer Clause") in its payor-provider contracts, stating the use was not anticompetitive. ${ }^{191}$ The

181. United States v. Grinnell Corp., 384 U.S. 563, 570-71 (1966).

182. See Blue Cross \& Blue Shield United of Wis. v. Marshfield Clinic, 65 F.3d 1406, 1415 (7th Cir. 1995); Ocean State Physicians Health Plan, Inc. v. Blue Cross \& Blue Shield of R.I., 883 F.2d 1101, 1108 (1st Cir. 1989).

183. Ocean State Physicians Health Plan, Inc., 883 F.2d at 1112.

184. Id.

185. COMPetition AND MonOPOLY, supra note 176.

186. Aspen Skiing Co. v. Aspen Highlands Skiing Corp., 472 U.S. 585, 605 n.32 (1985)

(quoting 3 Philip Areeda \& Donald F. Turner, Antitrust LaW 78 (1978)).

187. COMPETITION AND MONOPOLY, supra note 176.

188. Id.

189. See Blue Cross \& Blue Shield United of Wis. v. Marshfield Clinic, 65 F.3d 1406, 1415

(7th Cir. 1995); Ocean State Physicians Health Plan, Inc., 883 F.2d at 1108.

190. Marshfield Clinic, 65 F.3d at 1415.

191. Ocean State Physicians Health Plan, Inc., 883 F.2d at 1108. 
district court in Ocean State reasoned as an ordinary buyer of services, the insurer was entitled to bargain for the best price that it could obtain, especially when the prices obtained were not "predatory" or below market price, and the end result was lower prices for the ultimate consumer. ${ }^{122}$ The court expounded, stating as "a naked proposition, it would seem silly to argue that a policy to pay the same amount for the same services is anticompetitive, even on the part of one who has market power. This, it would seem, is what competition should be all about." 193 The Seventh Circuit has come to a similar conclusion regarding MFNs in Blue Cross \& Blue Shield United of Wisconsin v. Marshfield Clinic, holding MFNs "are standard devices by which buyers try to bargain for low prices by getting the seller to agree to treat the buyers as favorably as any of the seller's other customers." ${ }^{194}$ Instead, Judge Posner, the author of the opinion, stated as long as the MFNs are not misused, they can accomplish exactly "the sort of conduct that the antitrust laws seek to encourage." 195 The pervasive theme from both opinions is that MFNs can be a procompetitive device, so long as they are used to achieve equal prices or treatment "as favor[able] as any of [the health care providers'] other customers." 196

Conversely, the Tenth Circuit found a defendant liable for antitrust violations when it used MFNs to achieve illegal ends. ${ }^{197}$ The Tenth Circuit found in Reazin v. Blue Cross and Blue Shield of Kansas, Inc., the defendant in that case monopolized the health care financing market using MFNs. ${ }^{198}$ However, the court was careful to reconcile its decision with the First Circuit's holding in Ocean State, stating:

[T] he most favored nations clause here is not itself challenged as unlawful monopolization. Rather, it is only considered as evidence of, or as contributing to, Blue Cross' market or monopoly power. We need not reach the question addressed in Ocean State of whether use of the most favored nation's clause could itself violate section $2 .{ }^{199}$

As in other business dealings, Indiana employers must be aware of potential antitrust implications that arise from including MFNs into their payor-provider contracts. However, it is safe to infer from the guidelines announced by the federal enforcement agencies and the little case law available that Indiana employers may safely utilize MFNs in payor-provider contracts without raising antitrust implications.

192. Ocean State Physicians Health Plan, Inc. v. Blue Cross \& Blue Shield of R.I., 692 F. Supp. 52, 71 (D.R.I. 1988), aff'd, 883 F.2d 1101 (1st Cir. 1989).

193. Id.

194. Marshfield Clinic, 65 F.3d at 1415.

195. Id.

196. Id.; Ocean State Physicians Health Plan, Inc., 883 F.2d at 1108.

197. Reazin v. Blue Cross \& Blue Shield of Kan., Inc., 899 F.2d 951, 983 (10th Cir. 1990).

198. Id.

199. Id. at 983 n.30 (emphasis added). 


\section{CONCLUSION}

When used in the health care industry, Most Favored Nation Clauses are extremely polarizing contract provisions. When applied in a procompetitive manner, they can lead to lower prices for health care and the elimination of certain transactional costs that result from constant negotiations with health care providers.

However, MFNs have also been used for anticompetitive purposes. Insurance companies have used them as tools to influence the price of health insurance by setting price floors, eliminating the incentive for health care providers to grant any other parties discounts for services and forming barriers-of-entry to potential competitors in the health insurance marketplace. These anticompetitive effects have led federal antitrust enforcement agencies to file causes of action against some insurers who use MFNs and have even led several states to pass laws banning MFNs in payor-provider contracts.

The Indiana General Assembly itself enacted an anti-MFN statute, Indiana Code section 27-8-11-9, in the fall of 2007. However, two specific statutory provisions exist that allow Indiana employers to continue to use MFNs when providing self-funded health insurance plans to their employees. First, Indiana's anti-MFN statute includes an employer exemption, which exempts employers from its requirements so long as the employer is contracting to provide health insurance to its employees. ${ }^{200}$ Secondly, when employers structure their health plans as a self-funded employee benefit plan, ERISA's preemption provision preempts all Indiana laws that relate to it, including the anti-MFN statute. ${ }^{201}$ Together, these two independent statutory provisions ensure Indiana employers may legally use MFNs when contracting with health care providers to provide self-funded health care plans to their employees.

Finally, although there are undoubtedly antitrust implications that arise when MFNs are used in an anticompetitive manner, Indiana employers may avoid making these mistakes by having a thorough understanding of the recent trends in antitrust law. Specifically, federal enforcement agency guidelines and recent case law suggest when used in a procompetitive manner or by a business with less than a certain amount of market power, MFNs may be used without raising antitrust implications.

The bottom line is that the decision to use MFNs in contracts with health care providers is one that must be made by Indiana employers on a case-by-case basis, depending on both situational and economic factors. Regardless, should the decision to use MFNs make strategic sense, employers may legally use them.

200. IND. CODE $§ 27-8-11-9$ (b) (2015).

201. See 29 U.S.C. $\S 1144(a)$ (2012). 